\title{
KANDUNGAN SERAT, VITAMIN C, AKTIVITAS ANTIOKSIDAN DAN ORGANOLEPTIK KERIPIK AMPAS BROKOLI (Brassica oleracea var . italica) PANGGANG
}

\author{
Kristanti Novita Sari, Fitriyono Ayustaningwarno*)
}

Program Studi Ilmu Gizi Fakultas Kedokteran Universitas Diponegoro

J1.Dr.Sutomo No.18, Semarang, Telp (024) 8453708, Email : gizifk@ undip.ac.id

\begin{abstract}
Background : High saturated fat and low fiber, vitamins and antioxidants consumption are risk factors for cardiovascular disease. Broccoli contains vitamin C, fiber, phenolic compounds, glucosinolates and antioxidants. Broccoli can be consumed in the form of juice and it's pulp of often discarded. Broccoli pulp still contain dietary fiber, phenolic compounds and vitamin $C$, which can be utilized as chips. Broccoli pulp chips can be affect nutritional content such as vitamin $C$, fiber and antioxidants.

Objectives: Analyzing the content of fiber, vitamin $C$, antioxidant activity and organoleptic bake broccoli pulp chips (Brassica oleracea var.italica)

Methods: A completely randomized single factor-experimental study by pulp of broccoli variations (50\%,70\%,85\%). Analysis of protein content by the Kjeldahl method, fat by Soxhlet method, carbohydrate by difference method, fiber by thermogravimetric method, vitamin $C$ by iodine titration method, antioxidant activity by DPPH method and organoleptic tests include the level of preference aroma, color, texture and flavor.

Result: Pulping process reduce vitamin C content from 68.53 to $13.38 \mathrm{mg}$ and antioxidant activity from $78.20 \%$ to $8.18 \%$. The processing of broccoli pulp into chips decreased content of vitamin $C$ from 2.25 to $4.64 \mathrm{mg}$ and antioxidant activity increased 30.61 to $45.49 \%$. Chips nutritional content was 2.41 to $3.05 \mathrm{~g}$ protein; 5.63 to $5.95 \mathrm{~g}$ fat; 78.38 to $82.27 \mathrm{~g}$ carbohydrate; 1.73 to $2.74 \mathrm{~g}$ fiber; 2.25 to $4.64 \mathrm{mg}$ vitamin $\mathrm{C}$; 30.61 to $45.49 \%$ antioxidant activity. The most preferred of chips are pulp of broccoli chips $85 \%$.

Conclusion: The highest content of fiber, vitamin $C$ and antioxidant activity there is on the chips by using pulp of broccoli $85 \%, 2.74 \mathrm{~g}$ fiber; $4.64 \mathrm{~g}$ of vitamin $C$ and $45.9 \%$ antioxidant activity.
\end{abstract}

Keywords: Brocooli pulp chips, fiber, vitamin C, antioxidant activity

\begin{abstract}
ABSTRAK
Latar Belakang: Konsumsi makanan tinggi lemak jenuh dan rendah serat, vitamin dan antioksidan merupakan faktor risiko penyakit kardiovaskuler. Brokoli mengandung vitamin C, serat, senyawa fenolik, glukosinolat, dan tinggi antioksidan. Brokoli dapat dikonsumsi dalam bentuk sari dan seringkali ampasnya dibuang. Ampas brokoli masih mengandung serat pangan, senyawa fenolik dan vitamin $C$ yang dapat dimanfaatkan menjadi keripik. Pembuatan keripik dengan ampas brokoli dapat mempengaruhi kandungan gizi seperti vitamin $C$, serat dan
\end{abstract} antioksidan.

Tujuan: Menganalisis kandungan serat, vitamin C, aktivitas antioksidan dan organoleptik keripik ampas brokoli (Brassica oleracea var.italica) panggang

Metode: Merupakan penelitian dengan rancangan acak lengkap satu faktor, yakni variasi jumlah ampas brokoli $50 \%, 70 \%$ dan $85 \%$. Analisis kadar protein dengan metode Kjeldahl, lemak dengan metode Soxhlet, karbohidrat dengan metode by difference, serat dengan metode termogravimetri, vitamin $C$ dengan metode titrasi yodium dan aktivitas antioksidan dengan metode DPPH serta uji organoleptik meliputi tingkat kesukaan aroma, warna, tekstur dan rasa.

Hasil: Pengolahan brokoli segar menjadi ampas mengakibatkan kandungan vitamin c menurun dari 68,53mg menjadi 13,38mg dan aktivitas antioksidan menurun dari 78,20\% menjadi 8,18\%. Pengolahan ampas brokoli menjadi keripik mengakibatkan kandungan vitamin C menurun menjadi 2,25- 4,64 mg dan aktivitas antioksidan meningkat menjadi 30,61-45,49\%.Kandungan gizi keripik yakni protein 2,41-3,05 g; lemak 5,63-5,95g; karbohidrat 78,38-82,27g; serat 1,73-2,74 g; vitamin C 2,25-4,64 mg; aktivitas antioksidan 30,61-45,49\%. Keripik yang paling disukai panelis adalah keripik dengan penggunaan ampas $85 \%$.

Simpulan: Kandungan serat, vitamin $C$ dan aktivitas antioksidan tertinggi terdapat pada keripik dengan penggunaan ampas brokoli 85\%, yakni serat 2,74g; vitamin c 4,64 gr dan aktivitas antioksidan 45,9\%.

Kata kunci: keripik ampas brokoli, serat, vitamin C, aktivitas antioksidan

\section{PENDAHULUAN}

Faktor penyebab meningkatnya kejadian penyakit kardiovaskuler adalah adanya perubahan gaya hidup seperti merokok, konsumsi alkohol, kurangnya aktifitas fisik dan perubahan pola makan. ${ }^{1}$ Sebagian besar karena konsumsi makanan 
yang tidak seimbang, dimana konsumsi tinggi lemak jenuh dan rendah konsumsi serat, vitamin dan antioksidan seperti buah dan sayuran. Oleh karena itu, peran gizi dalam mengendalikan faktorfaktor risiko tersebut sangat besar untuk pencegahan penyakit kardiovaskuler. ${ }^{2}$

Telah dilakukan penelitian terhadap beberapa macam bahan pangan serta komponennya, yang hasilnya menunjukkan bahwa bahan pangan tersebut dapat menurunkan risiko timbulnya penyakit kardiovaskuler. Salah satu bahan pangan tersebut adalah sayuran dan buah buahan yang memilki efek protektif terhadap penyakit kardiovaskuler seperti penyakit jantung koroner. Sayuran dan buah -buahan mengandung zat gizi maupun non gizi seperti serat pangan, asam folat, flavonoid, karotenoid dan vitaminvitamin antioksidan. ${ }^{3}$

Brokoli (Brassica olaracea L.var italica) merupakan salah satu famili dari Brassicaceae yang mengandung fitokimia yang baik seperti glukosinolat, senyawa fenolik, serat dan senyawa antioksidan seperti vitamin $\mathrm{C}$ dan $\mathrm{E}$ serta mineral $(\mathrm{Ca}, \mathrm{Mg}, \quad \mathrm{Se}$,dan $\mathrm{K}){ }^{4}$ Dibandingkan dengan sayuran yang lain (wortel, kubis dan bayam) kandungan vitamin $\mathrm{C}$ dan serat pada brokoli lebih tinggi yaitu sebesar 89,2 mg dan 2,6 mg. ${ }^{5}$

Brokoli banyak dikonsumsi dalam bentuk olahan atau dimasak menjadi aneka sayur dan dikonsumsi dalam bentuk mentah atau segar. Brokoli juga dapat dimanfaatkan untuk diet dalam bentuk sari brokoli karena kandungan antioksidan yang bermanfaat bagi kesehatan. Dalam pembuatan sari brokoli ini seringkali ampas sisa produksi dibuang, padahal pada ampas masih mengandung serat pangan, vitamin $\mathrm{c}$ dan senyawa fenolik. ${ }^{6}$ Sebagian besar senyawa fenolik pada sayuran terdapat di bagian jaringan selulosa dan kompartemen intraseluler, saat sayur dipanaskan senyawa fenolik akan terlepas dari ikatannya. ${ }^{7}$

Sayur merupakan bahan pangan segar yang mudah rusak, upaya untuk memperpanjang masa simpan sayuran diperlukan teknologi yang dapat mengurangi kerusakan dan kebusukan sayuran. Salah satu alternatif yang dapat dilakukan adalah pembuatan keripik sayur. ${ }^{8}$ Keripik adalah makanan ringan (snack food) yang bersifat kering, renyah dan tahan lama. Keripik ini biasanya dibuat dari satu jenis bahan baku seperti kentang dan umbiumbian yang diiris tipis, tetapi pembuatan keripik dapat dibuat dengan menggunakan bahan baku adonan tepung, sehingga dapat memperbaiki kualitas keripik karena dapat menambahkan bahan lain yang dapat memperbaiki kandungan gizinya. ${ }^{9,10}$ Keripik merupakan jenis makanan yang sudah lama dikenal oleh sebagian konsumsi masyarakat sebagai camilan. Namun keripik yang ada di masyarakat pada umumnya didominasi oleh keripik hasil penggorengan yang memiliki kandungan lemak tinggi. Untuk meminimalkan kandungan lemak pada keripik dapat dilakukan dengan proses pemanggangan. ${ }^{11}$

Penggunaan ampas brokoli sebagai bahan utama dalam pembuatan keripik dengan proses pemanggangan dapat mempengaruhi zat gizi keripik seperti serat, vitamin $\mathrm{C}$ dan antioksidan. Maka dari itu dilakukan penelitian mengenai kandungan zat gizi dan organoleptik pada keripik ampas brokoli.

\section{METODE}

Penelitian yang dilakukan termasuk dalam bidang food production. Penelitian ini dilaksanakan mulai bulan Mei hingga Juni 2014 di Laboratorium Ilmu Teknologi Pangan Pangan Universitas Muhamadiyah Semarang.

Penelitian ini merupakan penelitian dengan rancangan acak lengkap satu faktor yaitu variasi jumlah ampas brokoli dengan 3 taraf perlakuan. Perlakuan didapatkan berdasarkan penelitian pendahuluan. Berdasarkan hasil penelitian pendahuluan penggunaan ampas di atas $85 \%$ dalam pembuatan adonan keripik tidak dapat menyatu, sehingga penggunaan ampas brokoli maksimal $85 \%$. Formulasi dalam penelitian ini dapat dilihat pada tabel 1 :

Tabel 1. Formulasi Keripik Ampas Brokoli

\begin{tabular}{lccc}
\hline Jenis bahan & \multicolumn{3}{c}{ Formulasi } \\
\cline { 2 - 4 } & T1 & T2 & T3 \\
\hline Ampas brokoli $(\mathrm{g})$ & 50 & 70 & 85 \\
Tepung terigu $(\mathrm{g})$ & 50 & 30 & 15 \\
Bawang merah $(\mathrm{g})$ & 1 & 1 & 1 \\
Bawang putih $(\mathrm{g})$ & 1 & 1 & 1 \\
Ketumbar $(\mathrm{g})$ & 1 & 1 & 1 \\
Garam $(\mathrm{g})$ & 1 & 1 & 1 \\
\hline
\end{tabular}


Bahan baku yang digunakan terdiri dari bagian bunga dan tangkai atas brokoli dengan kriteria bunga brokoli berwarna hijau gelap, rapat, bunga tidak terbuka, segar, tidak mengalami penyimpanan yang didapat dari Pasar Bandungan Ungaran, Tepung terigu merk "kunci biru", bawang merah, bawang putih, ketumbar dan garam diperoleh dari Pasar Bulu Semarang. Ampas brokoli diperoleh dengan cara brokoli segar dipotong, dicuci, diblansir $100^{\circ} \mathrm{C}$ selama 3 menit dan dihancurkan dengan juicer. Keripik dibuat dengan mencampurkan ampas brokoli, tepung terigu dan bumbu diaduk hingga homogen membentuk adonan. Adonan dipipihkan diatas loyang dan dipanggang dengan oven pada suhu $120^{\circ} \mathrm{C}$ selama \pm 45 menit.

Data yang dikumpulkan dari variabel terikat adalah data kandungan zat gizi dan organoleptik. Kandungan zat gizi meliputi kandungan protein dengan metode Kjeldahl, lemak dengan metode Soxhlet, karbohidrat dengan metode by difference, serat kasar dengan metode termogravimetri, vitamin $\mathrm{C}$ dengan metode titrasi yodium dan aktivitas antioksidan dengan metode DPPH serta uji organoleptik meliputi tingkat kesukaan aroma, warna, tekstur dan rasa.

Data yang terkumpul dianalisis dengan menggunakan program SPSS 16. Pengaruh variasi jumlah ampas brokoli pada keripik terhadap kandungan zat gizi protein, lemak, karbohidrat, serat, vitamin $\mathrm{C}$ dan aktivitas antioksidan diuji dengan One Way Anova dan dilanjutkan dengan Posthoc Test Tukey untuk mengetahui beda nyata antar perlakuan. Sementara itu, data organoleptik menggunakan uji Friedman dan uji lanjut Wilcoxon.

\section{HASIL}

\section{Perubahan kandungan vitamin $\mathrm{C}$ dan aktivitas antioksidan selama pengolahan}

Hasil perubahan kandungan vitamin $\mathrm{C}$ dan aktivitas antioksidan dilihat dari brokoli segar, ampas dan keripik brokoli dapat dilihat pada tabel 2 berikut.

Tabel 2. Hasil Analisis perubahan kandungan vitamin $\mathrm{C}$ dan aktivitas antioksidan

\begin{tabular}{lllll}
\hline Bahan & $\begin{array}{l}\text { Vitamin C } \\
(\mathrm{mg} / 100 \mathrm{~g})\end{array}$ & $\%$ & $\begin{array}{c}\text { Aktivitas antioksidan } \\
(\%)\end{array}$ & $\%$ \\
\hline Brokoli segar & $68,53 \pm 7,7^{\mathrm{a}}$ & 100 & $78,20 \pm 2,99^{\mathrm{a}}$ & 100 \\
Ampas brokoli & $13,38 \pm 0,66^{\mathrm{b}}$ & 19,52 & $8,18 \pm 1,01^{\mathrm{d}}$ & 10,46 \\
Keripik T1 $(50 \%)$ & $2,25 \pm 0,32^{\mathrm{c}}$ & 3,28 & $30,61 \pm 0,46^{\mathrm{c}}$ & 39,14 \\
Keripik T2(70\%) & $3,77 \pm 0,45^{\mathrm{c}}$ & 5,5 & $36,80 \pm 0,58^{\mathrm{c}}$ & 47,05 \\
Keripik T3(85\%) & $4,64 \pm 1,41^{\mathrm{c}}$ & 6,76 & $45,49 \pm 0,49^{\mathrm{b}}$ & 58,17 \\
\hline
\end{tabular}

Keterangan: Huruf yang berbeda dibelakang angka menunjukan adanya perbedaan yang nyata

Berdasarkan data tabel di atas kandungan vitamin $\mathrm{C}$ dan aktivitas antioksidan brokoli segar yakni sebesar $68,53 \mathrm{mg}$ dan $78,20 \%$, sedangkan kandungan vitamin $\mathrm{C}$ dan aktivitas antioksidan ampas brokoli menurun menjadi $13,38 \mathrm{mg}$ $(19,52 \%)$ dan $8,18 \% \quad(10,46 \%)$ dibandingkan dengan kandungan brokoli segar. Kandungan vitamin $\mathrm{C}$ keripik dibandingkan ampas brokoli menurun menjadi $2,25 \mathrm{mg}$ pada penggunaan ampas $50 \% ; 3,77 \mathrm{mg}$ pada penggunaan ampas $70 \%$ dan
4,64 mg pada penggunaan ampas $85 \%$. Aktivitas antioksidan keripik meningkat dibandingkan ampas brokoli menjadi $30,61 \%$ pada penggunaan ampas $50 \% ; 36,80 \%$ pada penggunaan ampas $70 \%$ dan $45,49 \%$ pada penggunaan ampas $85 \%$.

\section{Kandungan Zat Gizi Keripik Ampas Brokoli}

Hasil analisis kandungan zat gizi (protein, lemak, karbohidrat, serat, vitamin c dan aktivitas antioksidan) keripik ampas brokoli dapat pada tabel 3 berikut.

Tabel 3. Hasil Analisis Kandungan Zat Gizi Keripik Ampas Brokoli

\begin{tabular}{ccccccc}
\hline \multirow{2}{*}{$\begin{array}{c}\text { Perlakuan } \\
\text { penggunaan } \\
\text { ampas }\end{array}$} & $\begin{array}{c}\text { Protein } \\
(\%)\end{array}$ & $\begin{array}{c}\text { Lemak } \\
(\%)\end{array}$ & $\begin{array}{c}\text { Karbohidrat } \\
(\%)\end{array}$ & $\begin{array}{c}\text { Serat kasar } \\
(\mathrm{g} / 100 \mathrm{~g})\end{array}$ & $\begin{array}{c}\text { Vitamin C } \\
(\mathrm{mg} / 100 \mathrm{~g})\end{array}$ & $\begin{array}{c}\text { Aktivitas } \\
\text { antioksidan } \\
(\%)\end{array}$ \\
\hline T1 $(50 \%)$ & $2,41 \pm 0,04^{\mathrm{a}}$ & $5,63 \pm 0,12$ & $82,27 \pm 0,20^{\mathrm{c}}$ & $1,73 \pm 0,11^{\mathrm{a}}$ & $2,25 \pm 0,32^{\mathrm{a}}$ & $30,61 \pm 0,46^{\mathrm{a}}$ \\
$\mathrm{T} 2(70 \%)$ & $2,78 \pm 0,05^{\mathrm{b}}$ & $5,76 \pm 0,05$ & $80,83 \pm 0,11^{\mathrm{b}}$ & $2.27 \pm 0,09^{\mathrm{b}}$ & $3,77 \pm 0,45^{\mathrm{b}}$ & $36,80 \pm 0,58^{\mathrm{b}}$ \\
$\mathrm{T} 3(85 \%)$ & $3,05 \pm 0,06^{\mathrm{c}}$ & $5,95 \pm 0,04$ & $78,38 \pm 0,05^{\mathrm{a}}$ & $2,74 \pm 0,03^{\mathrm{c}}$ & $4,64 \pm 1,41^{\mathrm{c}}$ & $45,49 \pm 0,49^{\mathrm{c}}$ \\
\hline & $\mathrm{p}=0,001$ & $\mathrm{p}=0,081$ & $\mathrm{p}=0,000$ & $\mathrm{p}=0,001$ & $\mathrm{P}=0,000$ & $\mathrm{p}=0,000$ \\
\hline
\end{tabular}

Keterangan: Huruf yang berbeda dibelakang angka menunjukan adanya perbedaan yang nyata. 
Berdasarkan hasil statistik penggunaan jumlah ampas brokoli berpengaruh terhadap kandungan protein, karbohidrat, serat, vitamin c dan aktivitas antioksidan namun tidak berpengaruh terhadap lemak. Keripik penggunaan ampas 50\% memiliki kandungan karbohidrat tertinggi dan kandungan lemak terendah, dimana dalam $100 \mathrm{~g}$ terdapat karbohidrat $82,27 \mathrm{~g}$ dan lemak $5,63 \mathrm{~g}$. Keripik penggunaan ampas $85 \%$ memiliki kandungan protein, lemak, serat, vitamin $\mathrm{C}$, aktivitas antioksidan tertinggi dan kandungan karbohidrat terendah dimana dalam $100 \mathrm{~g}$ terdapat protein 2,05g; lemak 5,95g; serat 2,74g; vitamin C 4,64 mg; aktivitas antioksidan 45,9\% dan karbohidrat 78,38g.

\section{Organoleptik Keripik Ampas Brokoli}

Hasil analisis organoleptik tingkat kesukaan keripik ampas brokoli dengan parameter warna, aroma, tekstur, dan rasa dapat dilihat pada tabel 4 berikut.

Tabel 4. Hasil Analisis Uji Organoleptik Keripik Ampas Brokoli

\begin{tabular}{|c|c|c|c|c|c|c|c|c|}
\hline \multirow{2}{*}{$\begin{array}{l}\text { Perlakuan } \\
\text { penggunaan } \\
\text { ampas }\end{array}$} & \multicolumn{2}{|l|}{ Warna } & \multicolumn{2}{|l|}{ Aroma } & \multicolumn{2}{|l|}{ Tekstur } & \multicolumn{2}{|l|}{ Rasa } \\
\hline & Rerata & Ket & Rerata & Ket & Rerata & Ket & Rerata & Ket \\
\hline $\mathrm{T} 1(50 \%)$ & $3,00 \pm 0,19^{\mathrm{a}}$ & Netral & $3,28 \pm 0,12$ & Suka & $3,20 \pm 0,24^{\mathrm{ab}}$ & Suka & $2,56 \pm 0,17^{\mathrm{a}}$ & Netral \\
\hline $\mathrm{T} 2(70 \%)$ & $3,44 \pm 0,15^{\mathrm{ab}}$ & Suka & $3,44 \pm 0,19$ & Suka & $2,80 \pm 0,17^{\mathrm{a}}$ & Netral & $2,92 \pm 0,14^{\mathrm{a}}$ & Netral \\
\hline \multirow[t]{2}{*}{$\mathrm{T} 3(85 \%)$} & $3,80 \pm 0,18^{\mathrm{b}}$ & Suka & $3,40 \pm 0,18$ & Suka & $3,64 \pm 0,19^{\mathrm{b}}$ & Suka & $3,72 \pm 0,14^{\mathrm{b}}$ & Suka \\
\hline & $p=0,005$ & & $p=0,516$ & & $p=0,017$ & & $\mathrm{p}=0,000$ & \\
\hline
\end{tabular}

Keterangan: Huruf yang berbeda dibelakang angka menunjukkan adanya perbedaan yang nyata.

Secara statistik penggunaan jumlah ampas brokoli berpengaruh terhadap parameter warna, tekstur dan rasa keripik. Berdasarkan penilaian panelis uji tingkat kesukaan dinilai netral hingga suka. Keripik dengan penggunaan ampas 85\% memiliki tingkat kesukaan tertinggi dengan kategori suka pada paramater warna, aroma, tekstur dan rasa dibandingkan dengan penggunaan ampas $70 \%$ dan $50 \%$

\section{PEMBAHASAN}

\section{Perubahan kandungan vitamin $\mathrm{C}$ dan aktivitas antioksidan selama pengolahan}

Berdasarkan hasil penelitian kandungan vitamin C pada brokoli segar sebesar 68,53 mg dan ampas brokoli menurun menjadi $13,38 \mathrm{mg}$ $(19,52 \%)$. Aktivitas antioksidan pada brokoli segar $78,20 \%$ dan aktivitas antioksidan ampas brokoli menurun menjadi 8,18\%.

Penurunan kandungan vitamin $\mathrm{C}$ dan aktivitas antioksidan dikarenakan brokoli segar mengalami beberapa proses pengolahan seperti pemotongan, pencucian, blansir dan penghancuran. Vitamin $\mathrm{C}$ merupakan vitamin larut air yang mudah mengalami kerusakan akibat oksidasi, panas dan alkali. Proses pemotongan, pencucian, blansir dan penghancuran yang berlebihan dapat menyebabkan kandungan vitamin $\mathrm{C}$ pada bahan menjadi rusak. Proses pencucian dan blansir dengan air suhu $100^{\circ} \mathrm{C}$ dapat menurunkan kandungan vitamin $\mathrm{C}$ karena komponen vitamin $\mathrm{C}$ terlarut ke dalam air dan mengalami oksidasi oleh panas. Penurunan kadar vitamin $\mathrm{C}$ akibat pemotongan dan penghancuran membuat vitamin $\mathrm{C}$ pada bahan mudah teroksidasi dan akan memicu aktivitas enzim seperti peroksidase, asam askorbat oksidase dan fenolase. ${ }^{12,13}$

Asam askorbat sangat mudah teroksidasi menjadi asam L-dehidroaskorbat. Asam askorbat dan asam L-dehidroaskorbat masih mempunyai keaktifan sebagai vitamin C. Namun asam Ldehidroaskorbat bersifat sangat labil dan dapat mengalami perubahan menjadi L-diketogulonat. Ldiketogulonat yang terbentuk sudah tidak memiliki keaktifan vitamin $\mathrm{C}$ lagi. ${ }^{14}$

Pengujian kandungan vitamin $\mathrm{C}$ menggunakan metode titrasi yodium, dimana prinsipnya adalah yodium memiliki potensial reduksi yang lebih tinggi dibandingkan dengan asam askorbat, sehingga yodium akan mengoksidasi senyawa asam askorbat dengan membentuk asam dehidroaskorbat.L-diketogulonat memiliki sifat reduktor yang lemah dibandingkan asam askorbat dan dehidroaskorbat sehingga tidak dapat dioksidasi oleh yodium. Pengujian dengan metode ini cukup mudah dan relatih murah, namun kurang efektif untuk mengukur kandungan vitamin $\mathrm{C}$, karena dalam bahan pangan terdapat komponen lain selain vitamin $\mathrm{C}$ yang juga bersifat pereduksi. Senyawa tersebut mempunyai titik akhir yang sama dengan warna titik akhir titrasi vitamin C dengan iodin. Indikator titrasi menggunakan amilum untuk mengetahui titik akhir titrasi dengan memberikan perubahan warna menjadi biru kehitaman. $^{15}$ 
Kandungan vitamin $\mathrm{C}$ pada keripik dibandingkan dengan ampas brokoli menurun menjadi 2,25 mg pada keripik penggunaan ampas $50 \%$; $3,77 \mathrm{mg}$ pada keripik penggunaan ampas $70 \%$ dan 4,64 mg pada keripik penggunaan ampas $85 \%$. Aktivitas antioksidan pada keripik meningkat dibandingkan dengan aktivitas antioksidan ampas brokoli. Aktivitas antioksidan keripik penggunaan ampas $50 \%$ sebesar $30,61 \%$; keripik penggunaan ampas $70 \%$ sebesar $36,80 \%$ dan keripik penggunaan ampas $85 \%$ sebesar $45,49 \%$. Peningkatan aktivitas antioksidan pada keripik dibandingkan ampas brokoli dikarenakan penggunaan jumlah ampas brokoli pada tiap perlakuan berbeda dan adanya penambahan bahan lain seperti bawang merah, bawang putih dan ketumbar. Dimana dalam masing-masing bahan tersebut mengandung beberapa senyawa yang berpotensi sebagai antioksidan sehingga dapat meningkatkan aktivitas antioksidan keripik. Peningkatan ini sesuai dengan penelitian terdahulu pada keripik apel yang ditambah bawang merah dan bawang putih meningkat aktivitas antioksidannya, dimana keripik tanpa penambahan bawang merah dan bawang putih sebesar 16,19\%; penambahan bawang merah $26,15 \%$; penambahan bawang putih $22,87 \%{ }^{16}$ Sementara kandungan aktivitas antioksidan bawang putih $54,71 \%$, bawang merah 56,04\% dan ketumbar 50,39\%. ${ }^{17}$ Kandungan bawang putih yang berperan sebagai antioksidan antara lain alanine, $\alpha$ - tokoferol, asam askorbat, camphene, eugenol dan $\gamma$ - terpinen. ${ }^{18}$ Bawang merah mengandung senyawa kuersetin dan flavonoid yang berpotensi sebagai antioksidan. Ketumbar mengandung etil asetat yang berkontribusi sebagai antioksidan yang kuat. ${ }^{19}$

Proses pemanasan keripik dapat meningkatkan kandungan aktivitas antioksidan. Komponen aktif di dalam jaringan brokoli seperti senyawa fenolik dan senyawa glukosinolat akan meningkat oleh panas. Kandungan fenolik brokoli segar 1204,3 mg/g dan meningkat menjadi 1510,4 $\mathrm{mg} / \mathrm{g}$. Selama proses pemanasan dapat terjadi pembentukan senyawa baru yang berpotensi sebagai antioksidan melalui reaksi maillard. Senyawa yang terbentuk melalui reaksi maillard adalah senyawa melanoidin. Senyawa melanoidin mempunyai aktivitas antioksidan yang cukup besar, karena struktur melanoidin merupakan polimer ikatan rangkap karbon dan nitrogen tersier seperti enol atau enaminol yang mampu sebagai antioksidan. Gugus hidroksil pada melanoidin mampu mengurangi reduksi logam dan menangkap radikal bebas. ${ }^{20}$ Selain itu juga komponen antioksidan yang berikatan dengan polimer yang tidak terlarut, selama proses pemanasan ikatan tersebut akan dilepaskan sehingga dapat meningkatkan kandungan aktivitas antioksidan. ${ }^{21,22,23}$

\section{Kandungan Zat Gizi Keripik Ampas Brokoli}

Berdasarkan hasil analisis kandungan protein keripik ampas brokoli berkisar 2,41 - 3,05 g; kandungan lemak 5,63 - 5,95 g dan karbohidrat 78,38 - 82,27 g. Data kandungan protein, lemak dan karbohidrat digunakan untuk menghitung total energi dari masing-masing kelompok perlakuan. Total energi dari keripik ampas brokoli diperoleh dengan mengkonversikan karbohidrat, protein dan lemak, dimana dihasilkan 4 kkal per gram untuk karbohidrat dan protein serta 9 kkal per gram untuk lemak. ${ }^{24}$ Berdasarkan hasil perhitungan didapatkan total energi keripik penggunaan ampas 50\% sebesar $389 \mathrm{kkal}$ per $100 \mathrm{~g}$, penggunaan ampas $70 \%$ sebesar $386 \mathrm{kkal}$ per 100g dan penggunaan ampas $85 \%$ sebesar 379 kkal per 100g.

Perlakuan variasi jumlah ampas brokoli pada pembuatan keripik berpengaruh secara signifikan terhadap peningkatan kandungan serat kasar. Berdasarkan uji statistik menunjukan bahwa kandungan serat kasar keripik dengan penggunaan ampas brokoli 50\%, 70\% dan 85\% masing masing berbeda secara nyata. Kandungan serat kasar keripik ampas brokoli berkisar 1,73-2,74 g. Perbedaan kandungan serat kasar ini karena penggunaan jumlah ampas brokoli ke dalam masing - masing perlakuan, dimana semakin banyak penggunaan ampas brokoli maka berpengaruh juga terhadap peningkatan kandungan serat kasar keripik.

Analisis serat menggunakan metode termogravimetri, sehingga hanya diperoleh kandungan serat kasar. Kandungan serat kasar nilainya lebih rendah dibandingkan dengan serat pangan karena $\mathrm{H} 2 \mathrm{SO} 41,25 \%$ dan $\mathrm{NaOH} 1,25 \%$ mempunyai kemampuan yang lebih besar untuk menghidrolisis dibanding dengan enzim pencernaan sehingga terjadi kehilangan selulosa sekitar 50\% dan hemiselulosa $85 \%$. Sementara itu serat pangan masih mengandung komponen yang hilang tersebut. ${ }^{25}$

Asupan serat yang dianjurkan untuk dewasa \pm 25 /hari, sehingga dengan konsumsi tiap $100 \mathrm{~g}$ keripik ampas brokoli memberikan kontribusi serat sebesar $7-11 \%$. Konsumsi serat yang cukup dapat menurunkan kandungan kolesterol. Mekanisme penurunan kandungan kolesterol dengan serat yaitu serat di dalam tubuh dapat mengikat asam empedu sehingga akan meningkatkan ekskresinya serta 
menurunkan sintesis kolesterol dalam hati. Efek hipokolesterolemik serat pangan juga disebabkan karena adanya asam lemak berantai pendek seperti asetat, propionat dan butirat yang dihasilkan dari fermentasi serat. Asam - asam lemak inilah yang berfungsi dalam penurunan kandungan kolesterol. $^{26}$

Berdasarkan hasil uji statistik kandungan vitamin C keripik ampas brokoli terdapat perbedaan yang bermakna antar masing-masing perlakuan. Kandungan vitamin $\mathrm{C}$ pada keripik penggunaan ampas $50 \%$ sebesar $2,25 \mathrm{mg}$, penggunaan ampas $70 \%$ sebesar $3,77 \mathrm{mg}$ dan penggunaan ampas $85 \%$ sebesar $4,64 \mathrm{mg}$. Perbedaan kandungan vitamin $\mathrm{C}$ tiap kelompok perlakuan karena jumlah penggunaan ampas brokoli tiap kelompok perlakuan berbeda - beda.

Vitamin $\mathrm{C}$ atau asam askorbat merupakan antioksidan larut air utama dan menjadi bagian dari pertahanan pertama terhadap radikal bebas dengan mendonorkan elektron pada membran plasma.Vitamin $\mathrm{C}$ dapat melindungi biomembran dan LDL dari kerusakan peroksidatif. ${ }^{27}$

Defisiensi vitamin C atau asam askorbat dapat meningkatkan konsentrasi lipoprotein plasma. Meningkatnya lipoprotein plasma merupakan marker terbentuknya aterosklerosis. Sebaliknya, jika kandungan vitamin $\mathrm{C}$ atau asam askorbat di dalam plasma dan jaringan adekuat dapat menghambat terjadinya aterosklerosis dengan menurunkan konsentrasi lipoprotein plasma. Terhambatnya proses aterosklerosis ini berhubungan dengan penurunan risiko penyakit kardiovaskuler. $^{28}$

Aktivitas antioksidan keripik ampas brokoli tiap perlakuan terdapat perbedaan yang bermakna. Aktivitas antioksidan pada keripik penggunaan ampas $50 \%$ sebesar $30,61 \%$, penggunaan ampas $70 \%$ sebesar $36,80 \%$ dan penggunaan ampas $85 \%$ sebesar $45,49 \%$. Perbedaan aktivitas antioksidan tiap kelompok perlakuan karena jumlah penggunaan ampas brokoli tiap kelompok perlakuan berbeda - beda, selain itu adanya penambahan bahan lain seperti bawang merah, bawang putih dan ketumbar yang juga memiliki aktivitas antioksidan.

Aktivitas antioksidan merupakan parameter yang dapat menggambarkan persentase kemampuan suatu bahan makanan dalam menghambat radikal bebas. Antioksidan dapat melindungi tubuh dari setres oksidatif, mencegah LDL dari proses oksidasi dan memperlambat proses terjadinya aterosklerosis sehingga dapat menurunkan risiko penyakit kardiovaskuler. ${ }^{39}$

\section{Organoleptik Keripik Ampas Brokoli}

Berdasarkan hasil uji Friedman menunjukkan bahwa terdapat perbedaan yang bermakna antar ketiga perlakuan penggunan variasi jumlah ampas brokoli terhadap parameter warna, tekstur, dan rasa namun tidak pada parameter aroma.

Warna keripik ampas brokoli yang dihasilkan yaitu coklat kehijauan untuk keripik penggunaan ampas 50\%, hijau kecoklatan untuk keripik penggunaan ampas $70 \%$ dan hijau segar yang paling menarik untuk keripik penggunaan ampas $85 \%$. Warna hijau pada keripik berasal dari bahan yang digunakan yaitu ampas brokoli yang mengandung klorofil. Berdasarkan hasil analisis statistik nilai kesukaan tertinggi terdapat pada keripik penggunaan ampas brokoli $80 \%$ yaitu $3,80 \pm 0,18$.

Aroma keripik ampas brokoli memiliki tingkat kesukaan suka pada semua perlakuan. Panelis berpendapat bahwa keripik ampas brokoli memiliki aroma tidak langu dari brokoli. Aroma pada keripik tidak cenderung aroma sayur karena ada penambahan bawang dan ketumbar yang dapat menambah aroma pada keripik. Selain itu, pada proses persiapan brokoli diblansir terlebih dahulu pada suhu $100^{\circ} \mathrm{C}$ selama 3 menit untuk menginaktivasi enzim peroksidase yang menyebabkan aroma dan flavor yang tidak dikehendaki pada brokoli. ${ }^{30}$

Hasil uji kesukaan tekstur pada semua perlakuan keripik ampas brokoli adalah netral hingga suka dengan nilai kesukaan tertinggi yaitu $3,64 \pm 0,19$ pada keripik dengan penggunaan ampas brokoli $85 \%$. Panelis berpendapat bahwa keripik ampas brokoli perlakuan T3(85\%) memilki tekstur yang renyah dan serat brokoli masih terlihat dibandingkan dengan keripik perlakuan yang lain. Keripik dengan penggunaan ampas 50\% memiliki tekstur lebih keras, hal ini dikarenakan penggunaan tepung terigu lebih banyak dibandingkan dengan perlakuan yang lain. Tepung terigu berfungsi sebagai bahan pengikat terhadap ampas brokoli dalam adonan, dimana semakin banyak tepung terigu yang digunakan daya ikat dengan ampas brokoli semakin kuat dan membuat adonan semakin liat, sehingga berpengaruh terhadap tekstur keripik.

Keripik ampas brokoli memiliki rasa yang gurih, sehingga disukai panelis yang ditunjukkan dengan penilaian terhadap rasa yaitu netral hingga suka. Rasa gurih keripik berasal dari penambahan garam, bawang putih, bawang merah dan ketumbar. Keripik penggunaan ampas $85 \%$ lebih 
disukai panelis dengan nilai kesukaan tertinggi yaitu $3,72 \pm 0,14$. Berdasarkan pendapat panelis keripik penggunaan ampas $50 \%$ dan $70 \%$ rasa tepung masih dominan. Secara keseluruhan keripik ampas brokoli baik perlakuan penggunaan ampas $50 \%, 70 \%$ dan $85 \%$ dapat diterima oleh panelis baik dari segi warna, aroma, tekstur dan rasa, akan tetapi nilai kesukaan tertinggi terdapat pada keripik ampas brokoli dengan penggunaan ampas $85 \%$.

\section{SIMPULAN}

Pengolahan brokoli segar menjadi ampas brokoli mengakibatkan kandungan vitamin $\mathrm{C}$ dan aktivitas antioksidan menurun. Pembuatan keripik dari ampas brokoli mengakibatkan kandungan vitamin $\mathrm{C}$ menurun dan aktivitas antioksidan meningkat. Kandungan serat, vitamin $\mathrm{C}$ dan aktivitas antioksidan terbaik pada keripik dengan penggunaan ampas brokoli $85 \%$ yakni serat $2,74 \mathrm{~g}$; vitamin C 46,38mg; aktivitas antioksidan 45,9\% .Uji tingkat kesukaan keripik yang paling disukai panelis baik dari parameter warna, aroma, tekstur dan rasa dengan kategori suka adalah keripik dengan penggunaan ampas $85 \%$.

\section{SARAN}

Keripik yang direkomendasikan adalah keripik dengan penggunaan ampas brokoli $85 \%$ karena memiliki kandungan serat kasar, vitamin C dan aktivitas antioksidan tertinggi serta paling disukai panelis baik dari warna, aroma, tekstur dan rasa .

\section{DAFTAR PUSTAKA}

1. World Heart Federation. Risk Factor Cardiovascular Disease. April 2012. Diunduh dari http://www.world-heart-

federation.org/cardiovascularhealth/cardiovascular-disease-risk-factors/

2. WHO. Diet, Nutrition and Prevention of Chronic Diseases; Report of a Joint WHO/FAO Expert Consultation, Geneva, Switzerland, 2003.

3. Hu FB. Plant-Based Foods and Prevention of Cardiovascular Disease: An Overview. Am J Clin Nutr, 2003 ; 78(suppl).p.544-51

4. Moreno MC, Lopez-B, Gracia V. Chemical and Biological Characteristisation of Nutraceutical Compound Of Broccoli. journal of Pharmaceutical and Biomedical Analysis 2006; vol. 4.p.1508-22.

5. USDA.National Nutrient Database for Standard Reference26. Broccoli, Onion, Garlic and Coriander. United States : U.S: Departement of Agriculture Nutrient Data Laboratory and Health; 2012.

6. Aini N. Sumber serat yang bermanfaat. Kulinologi Indonesia. 2011. Vol (3).p.12-7
7. Bunea A, Andjeldkovic M, Socaciu C, Bobis O, NeacsuM, Verh'e R, Van Camp J. Total and Individual Carotenoids and Phenolic Acids Content in Fresh, Refrigerated And Processed Spinach (Spinacia Oleracea L.). Food Chem. 2008; vol 108:649-56.

8. Hambali, Erliza. Membuat Kripik Sayur. Jakarta : Penebar Swadaya. 2005.

9. Mursalina S, Silalahi J. Penetapan Kadar Serat Tak Larut Pada Makanan Keripik Simulasi. Journal of Natural Product and Pharmaceutical Chemistry. 2012;Vol 1.p.1-7.

10. Karebet WA. Optimasi Produksi Keripik Simulasi dari Ubi Kayu (Manihot esculenta Crantz) dan Ubi Jalar (Ipomea batatas L) Bersuplemen Protein Tepung Kedelai dan Tepung Beras [Skripsi]. Bogor: Institut Pertanian Bogor; 1999.

11. Muchtadi, Ayustaningwarno F. Teknologi Proses Pengolahan. Bandung : Alfabeta.2010

12. Shams E. Madiha M. Makhlouf. Ola SS. Effect of Some Cooking Methods on Natural Antioxidants And Their Activities in Some Brassica Vegetables.World Applied Science Journal.2013. 26 (6).p. 697-703

13. Fuad A, Rehab F.Bioactive Compound and Antioxidant Activity of Fresh and Processed White Cauliflower.Biomed Research International.2013

14. George FMB.Vitamins in Foods : Analysis, Bioavailability and Stability. New York:CRC Press Taylor and Francis.2009.p.292-4

15. Monalisa K, Fatimawali, Gayatri C. Perbandingan Hasil Penetapan Kadar Vitamin C Mangga Dodol Dengan Menggunakan Metode Spektrofotometri Uv-Vis Dan Iodometri. Jurnal Ilmiah Farmasi .2013.Vol. 2 ; 2302 - 2493

16. Tomas Z, Aleksandra D, Pawel S and Tadeusz.Production of Flavored Apple Chips of High Antioxidant Activity. Journal of Food Processing and Preservation.2010 ( 34) 728-742

17. Hala, M. Abdou. Comparative Antioxidant Activity Study of Some Edible Plants Used Spices in Egypt. Journal of American Science.2011;7(11)

18. Mishra Jyotsna, Srivastava RK, Shukia SV, Raghav CS. Antioxidant in Aromatic and Medical Plants. Science Tech Entrepreneur.2007

19. Wangensteen, H., A.B. Samuelsen, K.E. Malterud. Antioxidant Activity in Extracts from Coriander. Food chemistry Journal.2004 (88)

20. Echavarría, Pagán, Ibarz. A.Antioxidant activity of the malanoidin fractios formed D-Glucose and DFructose with L-Asparagine in the Mailard Reaction. Scientia Agropecuaria.2013.(4): 45 - 54

21. Nihal T, Ferda S. and Sedat V. The Effect of Cooking Methods on Total Phenolics and Antioxidant Activity of Selected Green Vegetables. Food Chemistry.2005; 93.p.713-718.

22. Oliviero T, Verkerk R,Dekker M. Effect of Water Content and Temperature on Glucosinolate Degradation Kinetics in Broccoli (Brassica 
oleracea var. italica). Food Chemistry. 2013. Volume 132, Issue 4, 15.p.2037-2045

23. Jimenez M, Garcia D, Martinez T, Marizcal, Murcia. Influence of Cooking Method on Antioxidant Activity of Vegetables. Journal of Food Science. 2009.vol.74(3).

24. Gallagher ML. The Nutrient and Their Metabolism. In: Mahan LK, Stump SE, editors. Krause's Food and the Nutrition Care Process 13th edition. Philadelphia: WB Saunders Company; 2012. p. 32-41.

25. Sudarmadji S, Haryono B, Suhardi. Penentuan Serat Kasar, Penentuan Pati. Prosedur Analisa untuk Bahan Makanan dan Pertanian. Yogyakarta: Liberty; 2007. p. 39-41.

26. Demigne C, Morand C, Levrat AM, Besson C. Effect Of Propionat On Fatty Acid and Cholesterol Synthesis And On Acetate Metabolism In Isolated Rat Hepatocytes.Br J Nutr.1995;74.p.209-219

27. Podsedek A. Natural Antioxidant and Antioxidant Capacity of Brassica Vegetables A Review. LWTFood Science And Technology 2007;40 (1) .p.1-11

28. Garry G, Duthie and Katrina MB. Reducing the Risk of Cardiovascular Disease. In: Israel G, editors. Functional Foods Designer Foods, Pharmafoods, Nutraceuticals. New York :Chapman and Hall;1994

29. Kristina S. Peran Antioksidan Flavonoid dalam Meningkatkan Kesehatan. Bina Widya.2012; 23 (3).p.135-140

30. Morales EF, Chandia VE and Cisneros Z. Thermal Inactivation Kinetics of Peroxidase and Lipoxygenase from Broccoli, Green Asparagus and Carrots. Food Chemistry and Toxicology. 2002; 67(1) 